\title{
Effects of Positive Corona Discharge on PH Value of Tap and Distilled Waters in Liquid system
}

\author{
Qusay Adnan Abbas \\ Department of Physics, College of Science, University of Baghdad, Baghdad-Iraq. \\ Email: Qusayiraqi@yahoo.com.
}

\begin{abstract}
In this paper, the effect of positive corona discharge on the PH values of tap and distilled waters are studied in water liquid system. The photographs of the results show that the shape of water drop that formed in the end of capillary tube is extended into a cone as well as a blue glow appears at the end of capillary tube. The size of cone decreases with increases of applied voltage and because of the change distance between the liquid electrode and the surface of liquid, the cone diameter at the end of capillary tube oscillates with period approximately $1 \mathrm{Sec}$. In addition, the PH values of both tested waters are constant when the applied voltage is less than $5 \mathrm{KV}$, while when the exterinal applied voltage is equal to or greater than $5 \mathrm{KV}$, the $\mathrm{PH}$ value of both water types are increases rapidly where the tap water shows increases rate larger than that for distilled water.
\end{abstract}

Keywords: Corona discharge, Liquid discharge, $\mathrm{PH}$ value, Tap water, Distilled water.

\section{Introduction}

Plasmas produced by electrical discharges in liquids are finding wide applicability in a number of modern technology areas. Wherease conventional gas discharges oberate in environments where the electrodes and insulating structures are fixed and operate with gas pressures typically at or below one atmosphere, discharges in liquids have the added complexity that the liquid can vaporizewhich leads to discontinuous liquid-vapour boundaries-and the liquid-vapour boundary is not fixed so that the discharges can exhibit much more complex hydrodynamic behaviour [1]. Electrical discharge in liquids have received particular attention because the nonthermal plasma generated by these discharges initiate various chemical and physical processes that can be potentially utilized in different environmental, biological, or medical applications. Depending on the type of discharge and the input energy, these processes include high electric fields, ultraviolet radiation, overpressure shock wave, and, of particular importance, the formation of various reactive chemical species such as radicals $(\mathrm{OH}, \mathrm{H}, \mathrm{O})$ and molecular species $\left(\mathrm{H}_{2} \mathrm{O}_{2}, \mathrm{H}_{2}, \mathrm{O}_{3}\right)[2,3]$. Many scientists deal with various types of discharge configration and several kinds of applied high voltage [4-13].

A corona discharge is an electrical discharge brought on by the ionization of a fluid surrounding a conductor which occurs when the potential gradient exceeds a threshold in situations where sparking is not favored. In corona discharge, a current develops between two high-voltage electrodes in a dielectric fluid, usually air, by ionizing the fluid so as to generate a plasma around one electrode. This leads to the collection of electrons and ions made by stripping the electrons from atoms and electronic emission from the negatively polarized electrode. The ions generated are used as the charge carries to other electrode. Corona discharge usullay involves two asymmetric electrodes, one highly curved (emitter, injector, or active conductor) and one of low curvature (collector).

\section{Experiment Set Up}

The experimental apparatus were illustrated in Fig.(1). The apparatus consisted of a glass vessel 1 of $250 \mathrm{~cm}^{3}$ in volume, which is filled with $150 \mathrm{~cm}^{3}$ of a water to be treated. Where the waters which are treated in this work are tap and distilled waters. The glass vessel had a rubber head 2 with a fixed electrode 3 and glass tube 4 of $2 \mathrm{~mm}$ in inner diameter: at the end of glass tube, glass capillary tube 6 of $0.12 \mathrm{~mm}$ in inner diameter was fastened. Above the head, reserve feed container 5 of $150 \mathrm{~cm}^{3}$ in volume for an electrode liquid was mounted on capillary tube 6. A poistive corona discharge was excited in air between the surface of liquid and liquid 
electrode. This discharge was powered by a regulated d.c. Power supply 8. Aballast resistor 7 of $2 \mathrm{M} \Omega$ was connected in series to the liquid electrode.

To run the experiment, liquids (tap water and distilled water) from a container 5 were sucked into tube 4 and capillary tube 6 with a rubber bulb. The length of capillary 6 was $4.5 \mathrm{~cm}$ and that of tube 4 was $2 \mathrm{~cm}$. the distance between the capillary end and the liquid surface was maintained at about $1 \mathrm{~cm}$.

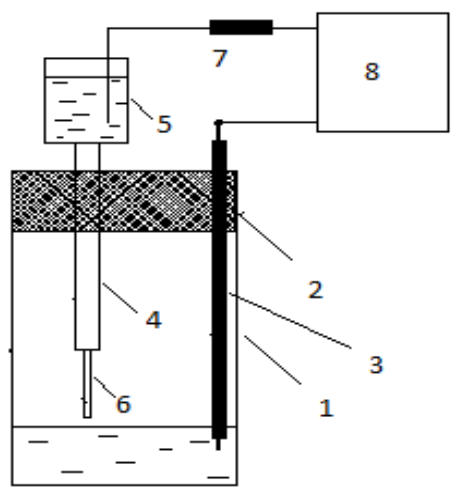

Fig. (1) Schematic of the experimental set up: 1) Glass reaction vessel,2) The glass vessel had a rubber head, 3) fixed electrode, 4) Glass tube, 5) container for the electrode liquid, 6) glass capillary tube, 7) ballast resistor, and 8) d.c. power supply.

\section{Results and Discussions}

The processes occurring at the tip of the capillary are illustrated in Figs. (2) and (3) which presents photographs of the electrode at various voltages for different waters (i.e. tap and distilled waters). These figures indicated the fact that, in the absence of the voltage, a drop is formed at the tip, which increases to large dimensions and falls. When the voltage is applied, the drop diameter increases, and the drop extends along the electrode axis. When the applied voltage $2 \mathrm{KV}$, the blue glow was appears at the end of the capillary tube and the drop extends into a cone. Where size of the cone decreases with increases of applied voltage. As well as, the cone diameter at the base of capillary tube oscillates with period approximately $1 \mathrm{sec}$. This oscillates in the cone diameters are due to the change distance between the liquid electrode and the surface of liquid. This behavior was shown in both waters.
Generally, because of the both waters under study are different in conductivity (where the measured electrical conductivity of tap and distilled waters is $30 \mu \mathrm{hm} / \mathrm{cm}$ and $18 \mu \mathrm{hm} / \mathrm{cm}$, respectively), so there are some different results can be seeing between both figures. The difference between both water are: the tap water shown high intensity discharge between the liquid electrodes. The shape of the cone that generated at the tip of capillary tube is different too.

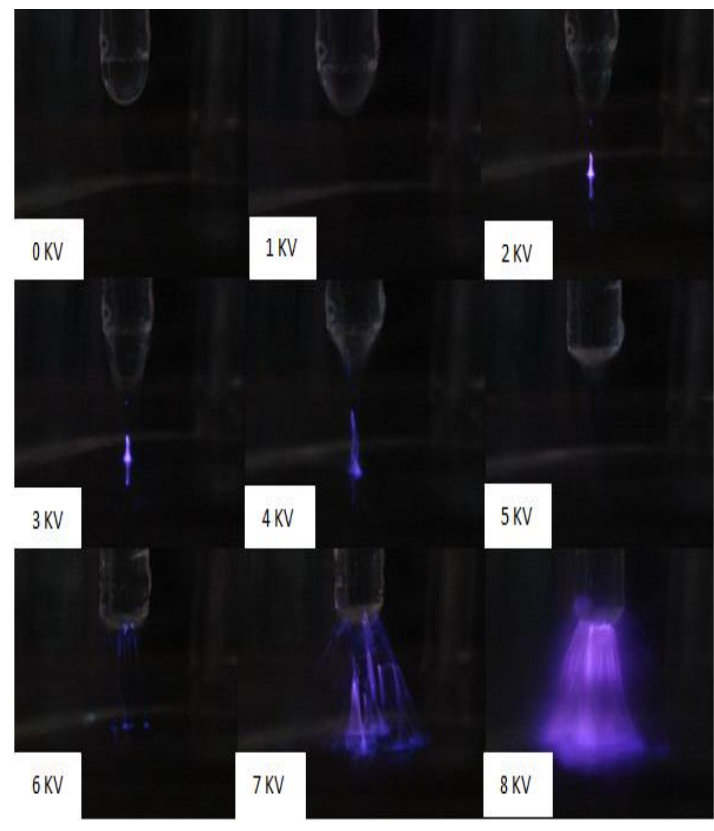

Fig. (2) Photograph of the tap water electrode without applied voltage and under different voltages.

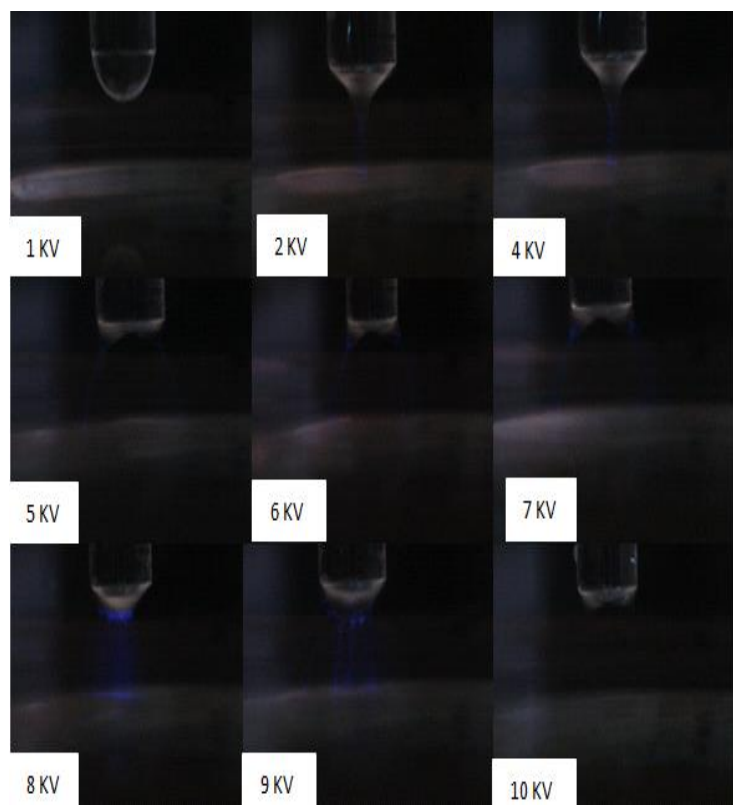

Fig. (3) Photograph of the distilled water electrode without applied voltage and under different voltages. 
However, few studies paid attention on the effect of corona discharge on the $\mathrm{PH}$ value of water. In this paper, we present the effect of corona discharge on the $\mathrm{PH}$ values of tap and distilled waters (see Fig.(4)).

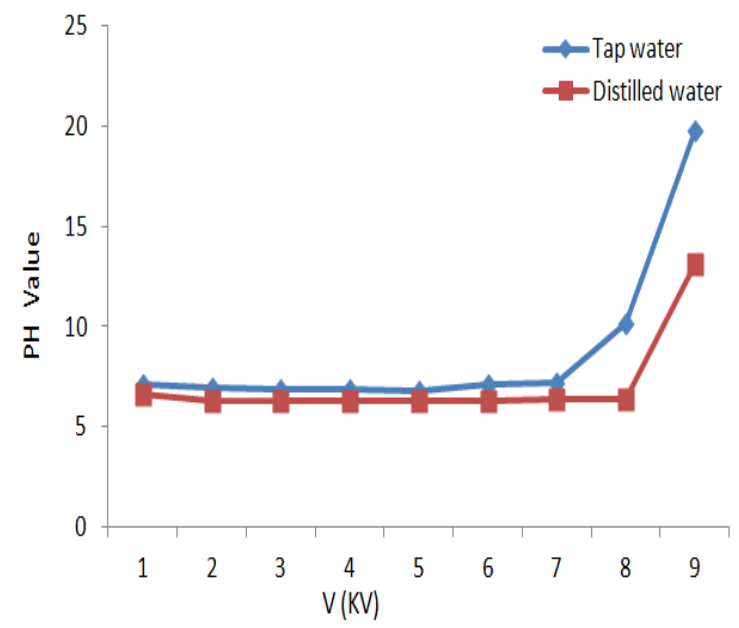

Fig. (4) The effect of corona discharge on the $P H$ value of tap and distilled waters in the liquid electrode system.

This figure indicated that, the $\mathrm{PH}$ value of the tap water is greater than that for distilled water and both water which under study have the same behavior with the applied voltage. In addition, the behavior of PH curve of both waters is approximatly constant under exterinal applied voltage less than $5 \mathrm{KV}$. While when the applied voltage greater than $5 \mathrm{KV}$, the $\mathrm{PH}$ value of both waters are increase rapidlly (where the increases rate of the tap water is greater than that for distilled water). This behavior is due to, the differences in the conductivity between both water types.

\section{Conclusions}

In this paper, we stuided the positive corona discharge that formated between two liquid electrodes in the tap and distilled waters. The results show the shape of cone that generated on the tip of capillary tube is different with conductivity of liquids. The blue glow appears at the end of capillary tube and the drop extends into a cone. In addition, the conducitivity is affected on the relationship between appears of the blue glow discharge with applied voltage. The size of the cone decreases with an increase in applied voltage. The cone diameter at the base of capillary tube oscillates with period approximately $1 \mathrm{Sec}$. this oscillate in the cone diameters are due to the change distance between the liquid electrode and the surface of liquid. The intensity of discharge that formed in tap water higher than from that formed in distilled water. In addiation, when the applied voltage $5 \mathrm{KV}$, the drope extends into two cones in the distilled water while this behavior did not appear in the tap water.

\section{References}

[1] Graham W., and Stalder K., "Plasmas in Liquids and Some of Their Applications in Nanoscience", J. Phys.D: Appl. Phys., 44, 174037, 2011.

[2] Lukes P., Clupek M., Babicky V., and Sunka P., "Pulsed Electrical Discharge in Water Generated Using Porous-CeramicCoated Electrodes", IEEE Trans. on Plas. Sci., 36, 4, 1146, 2008.

[3] Halamova I., Stara Z., Krcma F., "Interaction of Electrical Discharge with Water Solution of Humic Matters", Chem. Listy 102, s1368, 2008.

[4] Lu P., and Laroussi M., "Atmospheric Pressure Glow Discharge in Air Using a Water Electrode", IEEE Trans. on Plas. Sci., 33, 2, 272, 2005.

[5] Yang B., Lei L., and Zhou M., "Effect of the Liquid Conductivity on Pulsed HighVoltage Discharge Modes in Water", Chin. Chem. Let., 15, 10, 1215, 2004.

[6] Sato M., Soutome T., Mii S., Ohshima T., and Yamada Y., "Decompostion of Phenol in Water Using Water Surface Plasma in Wetted-Wall Reactor", Intern. J. of Plas. Envir. Sci. \&Techno., 1, 1, 71, 2007.

[7] Lukes P., Clupek M., Babicky V., and Sunka P., "Erosion of Needle Electrodes in Pulsed Corona Discharge in Water", Czechoslovak J. of Phys., 56, B916, 2006.

[8] Lukes P., Clupek M., Babicky V., "Discharge Filamentary Patterns Produced by Pulsed Corona Discharge at the Interface Batween a Water Surface and Air", IEEE Trans. on Plas. Sci., 39, 11, 2644, 2011.

[9] Sommers B., Foster J., Babaeva N., and Kushner M., "Observations of Electric Discharge Streamer Propagation and Capillary Oscillations on the Surface of 
Air Bubblesin Water", J. Phy. D: Appl. Phys., 44, 082001, 1, 2011.

[10] Sano N., Wang H., Alexandrou I., Chhowalla M., Teo K., Amaratunga G., "Properties of Carbon Onions Produced by an Arc Discharge in Water", J. of Appl. Phys., 92, 5, 2783, 2002.

[11] Miichi T., Hayashi N., Ihara S., Satoh S., and Yababe C., "Generation of Radicals Using Discharge Inside Bubbles in Water for Water Treatment", Report of Faculty of Sci. and Eng. Saga University, 31, 1, 1, 2002.

[12] Sabooni M.,and Ghanbarzadeh J., "Comparison of Tap Water, Distilled Water and Slurry Water on Surface Hardness of Gypsum Die", J. Med. Sci., 7, 8, 1350, 2007.

[13] Kolikov V., Pinchuk M., Leks A., and Rutberg P., "High-Speed Diagnostic Pulsewise-Periodic of Electric Discharge in a Water", Proc. of Spie., 6279, 62795C, 2007.

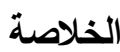

في هذا البحث، درس تأثنير التفريغ الاهليجي الموجب

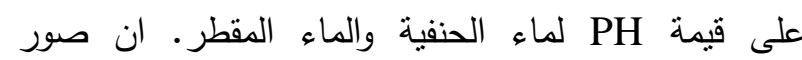
الفوتوغرافية لنتائج البحث تبين بأن شكل قطرة الماء المتكونة في نهاية الانبوب الثعري سوف تكون على شكل مخروط

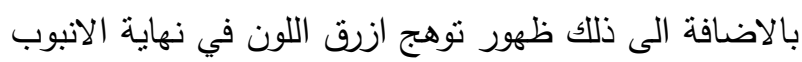
الثعري. وان حجم المخروط المتكون يقل مع زيادة الفولتية الخارجية المسلطة وبسبب كون ان المسافة بين قطب المائع وسطح الماء فأن المخروط المتككن في نهاية الانبوب الشعري سوف يتذبذب بمعدل زمني مقداره ثانية واحدة. وكما لوحظ بان قيم PH لكلا نوعي الماء تحت التجربة تكون ثابتة

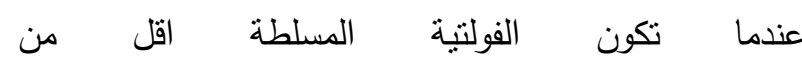
5 كيلو فولت، بينما تزداد قيم PH بشكل سريع لكلا نوعي

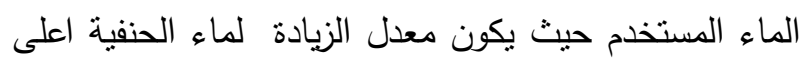
من الماء المقطر عندما تكون الفولطية المسلطة تساوي او اعلى من 5 كيلوفولط. 